\title{
Re-description of the loach species Leptobotia citrauratea (Teleostei, Botiidae), with the description of $L$. brachycephala from southern Zhejiang Province, China
}

\author{
Dong-Ming Guo ${ }^{1,2}$, E Zhang' \\ I Institute of Hydrobiology, Chinese Academy of Sciences, Wuhan, 430072, Hubei Province, China 2 University \\ of Chinese Academy of Sciences, Beijing, 100049, China \\ Corresponding author: E Zhang (zhange@ihb.ac.cn)
}

Academic editor: S. Kullander | Received 11 August 2020 | Accepted 22 January 2021 | Published 12 February 2021

http://zoobank.org/22E18CFF-5926-4283-B996-F937838A0712

Citation: Guo D-M, Zhang E (2021) Re-description of the loach species Leptobotia citrauratea (Teleostei, Botiidae), with the description of L. brachycephala from southern Zhejiang Province, China. ZooKeys 1017: 89-109. https://doi. org/10.3897/zookeys.1017.57503

\begin{abstract}
Leptobotia citrauratea (Nichols, 1925), a loach species, originally described from Dongting Lake, was recently rehabilitated, based on the examination of the holotype and non-topotypical specimens. Several field surveys conducted from 2016 to 2019 in Zhejiang, Jiangxi and Hunan Provinces, P.R. China, yielded many specimens of Leptobotia which were initially identified as L. citrauratea. Molecular and morphological analyses of these specimens demonstrated that two distinct species are involved. One was identified as $L$. citrauratea, represented by specimens from both the Poyang and Dongting Lake (type locality) systems in Jiangxi and Hunan Provinces, and the other species is described as L. brachycephala, represented by specimens from the Ou-Jiang and Qu-Jiang, two coastal rivers of Zhejiang Province, China. Leptobotia brachycephala resembles L. citrauratea and L. micra in having a row of orange dots or an orange stripe along the dorsal mid-line of the body, extending from the nape to the caudal-fin base - a unique character in Leptobotia. Leptobotia brachycephala differs from L. citrauratea and L. micra Bohlen \& Šlechtová, 2017, in caudal-fin shape and pelvic-fin insertion and proportional measurements including caudal-fin length, head length, predorsal length and anal-fin length. Its species status was further corroborated by position in a molecular phylogenetic analysis, based on the mitochondrial cyt b gene and its minimum uncorrected p-distance (2.9\%) from congeneric species.
\end{abstract}

\section{Keywords}

Biodiversity, Cypriniformes, morphology, phylogeny, taxonomy

Copyright Dong-Ming Guo, E Zhang. This is an open access article distributed under the terms of the Creative Commons Attribution License (CC BY 4.0), which permits unrestricted use, distribution, and reproduction in any medium, provided the original author and source are credited. 


\section{Introduction}

The loach genus Leptobotia was erected by Bleeker (1870) with the simultaneouslydescribed Leptobotia elongata (Bleeker, 1870) as type species by monotypy. The genus is distinguished from other genera of the family Botiidae by the presence of a simple suborbital spine beneath the eye (Tang et al. 2008). Sixteen species are currently included in Leptobotia (Kottelat 2012; Bohlen and Šlechtová 2016, 2017). The majority of these species are known from southern China, mainly in the Yangtze River (= Chang-Jiang) and Pearl River (= Zhu-Jiang) Basins and coastal rivers of southern Zhejiang Province. Two species - L. flavolineata Wang, 1981 and L. orientalis Xu, Fang \& Wang, 1981 occur in northern China (Tang et al. 2008; Kottelat 2012; Bohlen and Šlechtová 2017).

Nichols et al. (1925) described Leptobotia citrauratea from the Dongting Lake system in Hunan Province, China. Chen (1980) considered specimens of L. citrauratea to be juveniles of $L$. elongata. The synonymy of $L$. citrauratea with $L$. elongata was generally accepted by subsequent researchers (Kottelat 2004, 2012). However, Nalbant (2002) regarded L. citrauratea to be a valid species. Bohlen and Šlechtová (2017), based on examination of the holotype and non-topotypical specimens from the Poyang Lake system in Jiangxi Province, southern China, recognised L. citrauratea as a valid species. A row of orange dots or an orange stripe along the dorsal mid-line distinguishes it from L. elongata.

Several field surveys conducted by us from 2016 to 2019 in Zhejiang, Jiangxi and Hunan Provinces, yielded many specimens of Leptobotia with a row of orange dots or an orange stripe along the dorsal mid-line and orange or yellowish-brown lateral portion, by which they were initially identified as $L$. citrauratea. These specimens were recovered in two distinct lineages in a phylogenetic analysis, based on the mitochondrial cytochrome $b$ (cyt b) gene sequences. Morphological analysis also indicated that two distinct species are involved. One of them was identified as $L$. citrauratea, represented by specimens sampled from the Poyang and Dongting Lake systems. The other species is an undescribed species represented by specimens from the Ou-Jiang and $\mathrm{Qu}$-Jiang in Zhejiang Province. The present study aims to provide a re-description of L. citrauratea, based on fresh topotypical specimens and the formal description of the undescribed species.

\section{Materials and methods}

Specimens were either initially fixed in 10\% formalin and then transferred to $70 \%$ ethanol for morphological examination or preserved in 95\% ethanol for DNA extraction. Seventy-three specimens from the three species (L. citrauratea, L. elongata and $L$. brachycephala) were used for morphometric analysis. Voucher specimens are kept in the ichthyological collection of the Museum of Aquatic Organisms at the Institute of Hydrobiology (IHB), Chinese Academy of Sciences, Wuhan City, Hubei Province, China. 
Twenty-five measurements (Tables 1,2) were taken from 22 specimens of Leptobotia elongata collected from the upper Chang-Jiang Basin in Sichuan Province; 29 specimens of $L$. citrauratea from the Gan-Jiang (an effluent of Poyang Lake) and Dongting Lake; and 22 specimens of $L$. brachycephala from the Ou-Jiang and Qu-Jiang. Measurements were taken point to point with digital calipers directly linked to a datarecording computer and data recorded to the nearest $0.1 \mathrm{~mm}$. All measurements and counts were made on the left side of each specimen, following the methods of Kottelat (2001) and Xin et al. (2009). The lateral head length and measurements of other parts of the body were given as percentages of the standard length (SL) and measurements of parts of the head were expressed as proportions of the lateral head length (HL). Morphometric variation was analysed with Principal Component Analysis (PCA) in Past v.1.89 (Hammer et al. 2009). The PCA was made with log-transformed measurement data to a tenth of a millimetre in a covariance matrix and without rotation.

Genomic DNA was extracted from fin clips stored in ethanol using the TIANamp Genomic DNA Kit (Tiangen Biotech, Beijing) with the recommended protocol. The cyt $b$ gene was amplified by primers L14724 (GACTTGAAAAACCACCGTTG) and H15915 (CTCCGATCTCCGGATTACAAGAC) adopted from Xiao et al. (2001), with $1 \mu \mathrm{l}$ of each primer, $1 \mu \mathrm{l}$ template DNA, $12.5 \mu \mathrm{l}$ Master mix Taq (Beijing TsingKe Biotech Co. Ltd.) and $9.5 \mu$ double distilled water $\left(\mathrm{dd}_{2} \mathrm{O}\right)$ for a total reaction volume of $25 \mu$ l. The thermocycling conditions were as follows: initial denaturation for 4 min at $94^{\circ} \mathrm{C}$, denaturation for $50 \mathrm{~s}$ at $94^{\circ} \mathrm{C}$, annealing for $50 \mathrm{~s}$ at $55^{\circ} \mathrm{C}$ and extension for $1 \mathrm{~min}$ at $72{ }^{\circ} \mathrm{C}$. After $34-35$ cycles, the final extension was done at $72{ }^{\circ} \mathrm{C}$ for $10 \mathrm{~min}$ and the PCR product was preserved at $4{ }^{\circ} \mathrm{C}$. Sequencing was carried out by the Tianyihuiyuan Biotechnology Company.

A total of 98 cyt b sequences were generated from 12 species of Leptobotia. These sequences were used for phylogenetic analysis together with five sequences from two congeneric species (L. posterodorsalis Lan \& Chen, 1992 and L. elongata) and two sequences serving as outgroup (Parabotia fasciata Dabry de Thiersant, 1872 and P. lijiangensis Chen, 1980) downloaded from GenBank (Table 3).

The sequences were aligned utilising MAFFT version 7 (Katoh and Standley 2013) and ends trimmed, for a total alignment length of $1060 \mathrm{bp}$. The genetic distance, based on the uncorrected p-distance model (Kumar et al. 2016), was calculated with MEGA 7.0. DNASP v.5 was utilised to filter the haplotype (Librado and Rozas 2009).

PhyloSuite (Zhang et al. 2020) was used for phylogenetic analyses. The selection of the best-fit model of nucleotide evolution based on Akaike's Information Criterion was performed in ModelFinder (Kalyaanamoorthy et al. 2017). MrBayes 3.2.6 (Ronquist et al. 2012) was utilised for Bayesian analysis with the selected model: GTR+I+G+F, applying the optimal nucleotide evolution model and the MCMC method with four chains (three hot chains and one cold chain) running simultaneously for 6,000,000 generations to calculate posterior probability. Trees were sampled for every $1000 \mathrm{cy}$ cles. The initial $25 \%$ of sampled data were discarded as burn-in. Sufficient mixing of the chains was regarded to be reached when the average standard deviation of split frequencies was below 0.01 . 


\section{Taxonomy}

\section{Leptobotia citrauratea Nichols, 1925}

(Fig. 1a-c)

Botia citrauratea Nichols, 1925: 5 [Tungting [ now Dongting] Lake, Hunan Province Leptobotia elongata: Chen, 1980: 14 (no localities). Kottelat, 2004:15 (no localities); 2012:16 (no locality)

Leptobotia citrauratea: Nalbant, 2002: 316 (no localities). Bohlen \& Šlechtová, 2017: 90 (Nanchang City, Jiangxi Province)

Material examined. Leptobotia citrauratea: AMNH 8402, holotype, 50 mm SL; China: Hunan Province: Dungting Lake (photograph examined); collected by Clifford $\mathrm{H}$. Pope, 29 December 1921; IHB 2017100260-65, 201801026314, 201711016295, 201711015676,201711015673-74,201711015715-16,201711016204,201707028880, 201711015718, 201707028888, topotypes, 17 specimens, 47.0-65.3 mm SL; China: Hunan Province: Nanxian County: Dongting Lake; $2^{\circ} 2^{\prime} 29^{\prime \prime N}, 112^{\circ} 18^{\prime} 22^{\prime \prime E}$; collected by C.T An, November 2017; IHB 2017056850-60, 2017056862, 12 specimens, 33.342.7 mm SL; China: Jiangxi Province: Nanchang City: Gan-Jiang, an effluent of Poyang Lake; 2832'12"N, 11549'24"E; collected by D.M. Guo, November 2019.

Diagnosis. Leptobotia citrauratea shares with $L$. micra and L. brachycephala the unique presence of a row of orange spots or an orange stripe along the dorsal mid-line of the body, extending from the nape to the caudal-fin base. It differs from L. micra and $L$. brachycephala by having a deeply forked (vs. emarginate) caudal fin (length of median rays 1.7-2.3 times in length of upper lobe vs. 1.3-1.4 in L. micra and 1.2-1.5 in $L$. brachycephala), pelvic fin inserted slightly posterior or inferior (vs. slightly anterior in L. brachycephala) to the dorsal-fin origin, a longer head (22.5-26.8\% SL vs. $18.4-22.8 \%$ SL in L. brachycephala) and a shorter predorsal distance (51.4-56.3\% SL vs. $58.1-59 \%$ SL in L. micra) (Table 2, Fig. 2).

Description. Morphometric data for specimens examined in Tables 1, 2. See Fig. 1 for lateral and dorsal view of body. Body slender, strongly compressed laterally, with maximum depth at dorsal-fin origin. Predorsal body profile slightly convex. Ventral profile of head slightly concave or straight; ventral profile of body almost straight or slightly concave from pectoral-fin insertion to anal-fin origin and slightly convex from anal-fin origin to caudal-fin base. Lateral line nearly complete, extending along midlateral of body. Cheek and trunk covered with minute scales.

Head short, compressed laterally, length greater than maximum body depth. Snout slightly concave in lateral view, slightly shorter than postorbital head. Eye small, dorsolateral, in upper half of head; diameter less than interorbital space. Mouth inferior, with opening laterally extended to vertical through anterior margin of nostril. Buttonlike fleshy protrusion in gular region absent. Two rostral barbels at tip of snout. Maxillary barbel in corner of mouth, reaching beyond vertical through posterior margin of nostrils, not or just approaching to level of anterior margin of eye. Simple suborbital spine ventral to anterior margin of eye, reaching posterior margin of eye. 

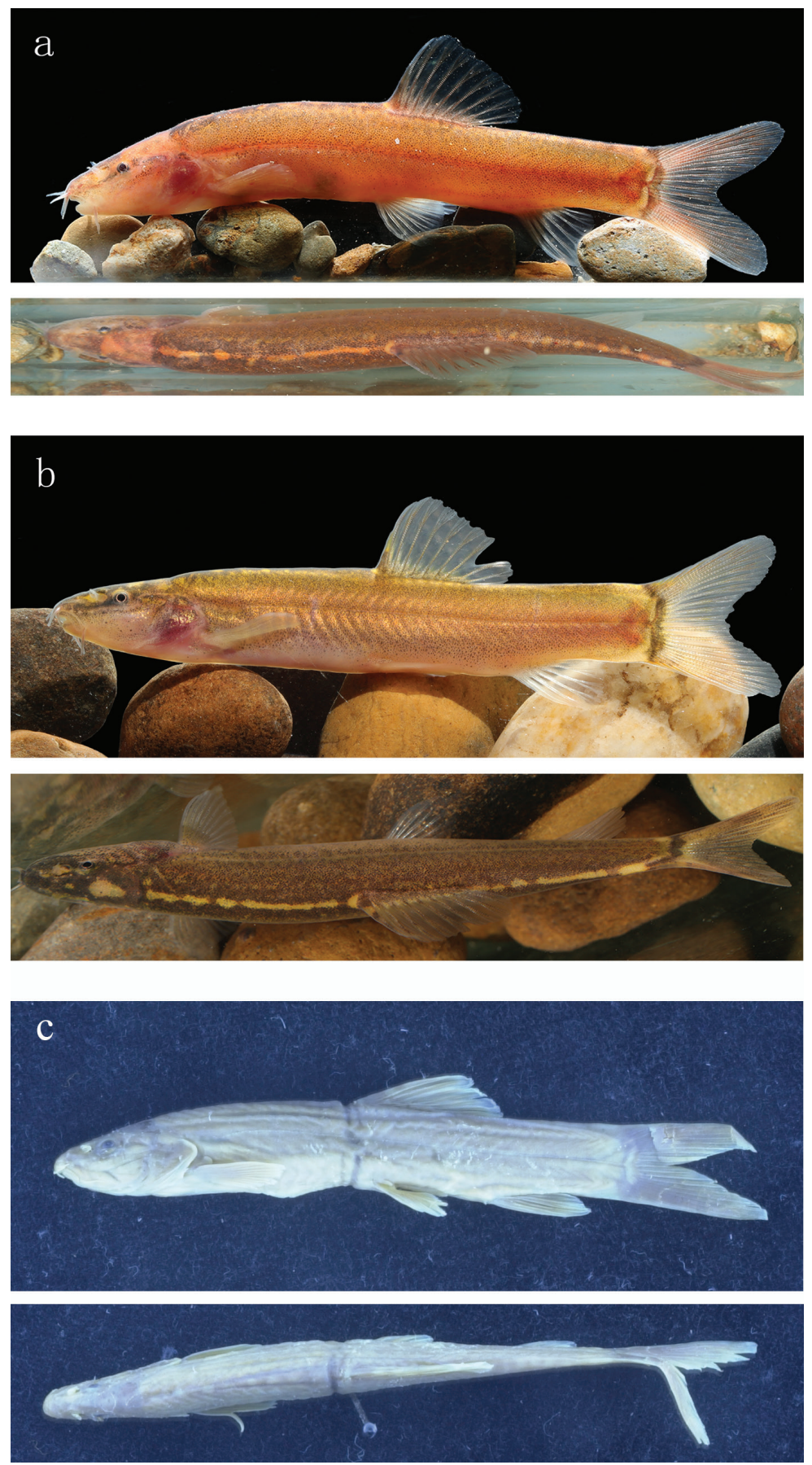

Figure I. Lateral (upper) and dorsal (lower) view of L. citrauratea for freshly-caught specimens a IHB 2017100265, topotype, 53.0 mm SL, China, Hunan Province, Yiyang City, Nanxian County, Dongting Lake b IHB 2017056850, 38.1 mm SL, China, Jiangxi Province, Nanchang City, Gan-Jiang c AMNH 8402, holotype, $50 \mathrm{~mm}$ SL, China, Hunan Province, Dungting (presently Dongting) Lake (photos by Department of Ichthyology, American Museum of Natural History). 
Table I. Morphometric measurements for three species of Leptobotia: L. citrauratea, L. elongata and L. brachycephala.

\begin{tabular}{|c|c|c|c|c|c|c|c|c|c|}
\hline \multirow[b]{4}{*}{$\mathrm{SL}(\mathrm{mm})$} & \multicolumn{4}{|c|}{ L. citrauratea } & \multirow{3}{*}{\multicolumn{2}{|c|}{$\begin{array}{c}\text { L. elongata } \\
\text { Chang-Jiang }(\mathrm{n}=\mathbf{2 2}) \\
\text { Range Mean } \pm \text { SD }\end{array}$}} & \multicolumn{3}{|c|}{ L. brachycephala sp. nov. } \\
\hline & \multirow{2}{*}{\multicolumn{2}{|c|}{$\begin{array}{c}\text { Dongting Lake }(\mathbf{n}=\mathbf{1 7}) \\
\text { Range Mean } \pm \text { SD }\end{array}$}} & \multirow{2}{*}{\multicolumn{2}{|c|}{$\begin{array}{c}\text { Poyang Lake }(\mathbf{n}=12) \\
\text { Range Mean } \pm \text { SD }\end{array}$}} & & & \multirow{3}{*}{$\begin{array}{c}\text { Holotype } \\
63.9 \\
\end{array}$} & \multicolumn{2}{|c|}{ Paratypes $(n=21)$} \\
\hline & & & & & & & & Range & \multirow{2}{*}{$\begin{array}{r}\text { Mean } \pm \text { SD } \\
56.1 \pm 5.7\end{array}$} \\
\hline & $47.0-65.3$ & $52.9 \pm 4.2$ & $33.3-42.7$ & $37.5 \pm 2.6$ & $97.8-272.0$ & $180.2 \pm 52.1$ & & $43.7-66.8$ & \\
\hline \multicolumn{10}{|l|}{ Morphometric data } \\
\hline \multicolumn{10}{|l|}{$\%$ of SL } \\
\hline Body depth & $14.8-18.8$ & $16.7 \pm 1.4$ & $15.7-19.2$ & $17.2 \pm 1.0$ & $17.3-23.7$ & $20.0 \pm 1.7$ & 12.9 & $11.1-15.8$ & $12.8 \pm 1.1$ \\
\hline Body width at dorsal origin & $8.7-12.5$ & $10.5 \pm 1.1$ & $9.7-12.4$ & $11.4 \pm 0.8$ & $8.3-14.9$ & $11.4 \pm 1.5$ & 7.6 & $6.3-9.7$ & $8.3 \pm 0.9$ \\
\hline Head length & $22.5-25.6$ & $24.2 \pm 0.8$ & $23.8-26.8$ & $25.4 \pm 0.8$ & $24.4-31.4$ & $27.8 \pm 1.8$ & 19.9 & $18.4-22.8$ & $20.6 \pm 1.1$ \\
\hline Dorsal-fin length & $14.9-18.0$ & $16.9 \pm 0.9$ & $13.7-16.8$ & $14.9 \pm 1.0$ & $16.3-22.0$ & $18.7 \pm 1.6$ & 10.6 & $9.0-11.6$ & $10.3 \pm 0.7$ \\
\hline Pectoral-fin length & $14.8-21.1$ & $17.0 \pm 2.0$ & $13.8-17.5$ & $15.6 \pm 1.0$ & $14.4-18.2$ & $16.8 \pm 0.9$ & 12.8 & $9.6-14.2$ & $11.9 \pm 1.1$ \\
\hline Pelvic-fin length & $12.7-16.9$ & $13.7 \pm 1.1$ & $12.1-14.3$ & $13.3 \pm 0.6$ & $13.3-16.3$ & $14.9 \pm 0.7$ & 10.2 & $9.1-12.6$ & $10.6 \pm 0.9$ \\
\hline Anal-fin length & $14.7-17.7$ & $16.3 \pm 0.8$ & $13.0-15.9$ & $14.2 \pm 0.9$ & $15.8-20.2$ & $18.0 \pm 1.2$ & 9.3 & $8.1-11.4$ & $10.0 \pm 0.8$ \\
\hline Upper caudal-lobe length & $23.6-26.9$ & $25.5 \pm 0.9$ & $23.6-26.7$ & $25.1 \pm 1.0$ & $23.1-30.0$ & $25.9 \pm 2.1$ & 18.4 & $15.2-20.8$ & $17.9 \pm 1.5$ \\
\hline Median caudal-ray length & $11.5-13.7$ & $12.4 \pm 0.6$ & $13.2-15.0$ & $14.2 \pm 0.5$ & $9.6-13.1$ & $10.7 \pm 1.0$ & 13.0 & $11.5-15.0$ & $13.0 \pm 0.9$ \\
\hline Caudal-peduncle length & $12.1-15.8$ & $13.9 \pm 0.9$ & $12.5-14.2$ & $13.3 \pm 0.5$ & $13.8-17.1$ & $15.5 \pm 0.9$ & 17.3 & $14.6-20.0$ & $17.7 \pm 1.6$ \\
\hline Caudal-peduncle depth & $10.4-12.9$ & $11.6 \pm 0.7$ & $11.3-13.5$ & $12.3 \pm 0.7$ & $10.9-13.8$ & $12.1 \pm 0.7$ & 11.5 & $10.3-14.4$ & $11.7 \pm 1.1$ \\
\hline Caudal-peduncle width & $2.1-3.9$ & $2.9 \pm 0.7$ & $3.2-4.2$ & $3.7 \pm 0.3$ & $2.6-4.8$ & $3.6 \pm 0.6$ & 2.8 & $1.7-4.3$ & $3.1 \pm 0.8$ \\
\hline Predorsal length & $51.4-56.3$ & $54.0 \pm 1.2$ & $52.8-55.3$ & $53.9 \pm 0.7$ & $54.5-58.8$ & $56.5 \pm 1.2$ & 51.7 & $49.9-54.7$ & $52.7 \pm 1.6$ \\
\hline Prepectoral length & $21.7-26.8$ & $23.7 \pm 1.1$ & $23.4-25.5$ & $24.5 \pm 0.6$ & $25.1-31.6$ & $28.3 \pm 1.8$ & 19.7 & $18.9-23.4$ & $20.5 \pm 1.1$ \\
\hline Prepelvic length & $53.2-59.0$ & $56.5 \pm 1.7$ & $52.3-56.0$ & $54.4 \pm 1.2$ & $56.0-61.5$ & $57.8 \pm 1.6$ & 49.2 & $47.9-53.1$ & $50.9 \pm 1.5$ \\
\hline Preanal length & $76.7-81.4$ & $79.0 \pm 1.3$ & $75.0-81.3$ & $78.1 \pm 1.6$ & $75.9-79.8$ & $77.4 \pm 1.1$ & 74.6 & $70.2-76.9$ & $73.8 \pm 1.6$ \\
\hline Vent to anal distance & $6.8-10.3$ & $8.9 \pm 0.9$ & $6.7-8.3$ & $7.5 \pm 0.6$ & $6.1-10.1$ & $8.4 \pm 1.1$ & 10.4 & $7.4-10.7$ & $9.3 \pm 0.9$ \\
\hline Pelvic to anal distance & $19.9-25.7$ & $22.9 \pm 1.8$ & $20.2-23.6$ & $21.4 \pm 1.1$ & $16.5-23.0$ & $19.3 \pm 1.5$ & 24.4 & $20.3-24.6$ & $22.0 \pm 1.3$ \\
\hline \multicolumn{10}{|l|}{$\%$ of $\mathrm{HL}$} \\
\hline Head depth at nape & $56.4-63.1$ & $59.3 \pm 1.6$ & $55.0-62.8$ & $58.8 \pm 2.0$ & $53.6-64.2$ & $57.4 \pm 2.8$ & 51.8 & $49.0-56.8$ & $52.8 \pm 2.6$ \\
\hline Head depth at eye & $42.3-48.4$ & $45.8 \pm 2.1$ & $43.6-49.7$ & $47.0 \pm 1.8$ & $40.5-48.5$ & $43.7 \pm 2.1$ & 38.6 & $37.7-45.8$ & $41.8 \pm 2.7$ \\
\hline Snout length & $35.4-43.9$ & $39.6 \pm 2.3$ & $35.1-42.5$ & $38.4 \pm 2.0$ & $35.7-42.6$ & $38.4 \pm 2.1$ & 36.2 & $35.6-41.8$ & $38.2 \pm 2.3$ \\
\hline Postorbital head length & $48.5-54.8$ & $51.6-2.0$ & $50.8-55.2$ & $52.5 \pm 1.6$ & $54.5-61.9$ & $57.8 \pm 1.9$ & 55.2 & $52.4-60.0$ & $56.2-2.6$ \\
\hline Eye diameter & $9.2-12.1$ & $10.3 \pm 1.0$ & $9.3-10.8$ & $10.0 \pm 0.5$ & $4.2-8.4$ & $6.0 \pm 1.1$ & 11.4 & $9.1-12.2$ & $10.4 \pm 0.9$ \\
\hline Interorbital width & $14.5-22.8$ & $17.3 \pm 2.4$ & $16.1-19.6$ & $17.7 \pm 1.1$ & $12.3-17.7$ & $14.8 \pm 1.5$ & 17.2 & $11.7-17.8$ & $15.1 \pm 2.1$ \\
\hline
\end{tabular}

Table 2. Major diagnostic characters amongst three species with a continuous or discontinuous orange line along the dorsal mid-line of the back. Data utilised for L. micra are from Bohlen and Šlechtov (2017).

\begin{tabular}{l|c|c|c}
\hline \multicolumn{1}{c|}{ Character } & L. brachycephala sp.nov. $(\mathbf{n}=\mathbf{2 2})$ & $\mathbf{L}$ c itrauratea $\mathbf{( n = 2 9 )}$ & $\mathbf{L .}$ micra $(\mathbf{n}=\mathbf{5})$ \\
\hline Colour on the back of body & $\begin{array}{c}\text { A continuous or discontinuous } \\
\text { orange line along dorsal mid-line }\end{array}$ & $\begin{array}{c}\text { A row of rounded orange spots } \\
\text { along the dorsal mid-line }\end{array}$ & $\begin{array}{c}\text { A row of rounded orange spots } \\
\text { along the dorsal mid-line }\end{array}$ \\
\hline Dorsal-fin origin & $\begin{array}{c}\text { Slightly posterior to pelvic-fin } \\
\text { insertion }\end{array}$ & $\begin{array}{c}\text { Slightly anterior to or superior to } \\
\text { pelvic-fin insertion }\end{array}$ & $\begin{array}{c}\text { Slightly posterior to or superior to } \\
\text { pelvic-fin insertion }\end{array}$ \\
\hline Caudal-fin shape & $\begin{array}{c}\text { Emarginate with rounded lobes; } \\
\text { median rays } 1.2-1.5 \text { times as long } \\
\text { as upper lobe. }\end{array}$ & $\begin{array}{c}\text { Strongly forked, with broadly } \\
\text { pointed lobes; median rays } \\
1.7-2.3 \text { times as long as upper } \\
\text { lobe. }\end{array}$ & $\begin{array}{c}\text { Moderately forked, with broadly } \\
\text { pointed lobes; median rays } \\
1.3-1.4 \text { times as long as upper } \\
\text { lobe. }\end{array}$ \\
\hline Predorsal length & $49.9-54.7$ & $51.4-56.3$ & $58.1-59.0$ \\
\hline Body depth (\% SL) & $11.1-15.8$ & $14.8-19.2$ & $15.3-18.3$ \\
\hline Head length (\% SL) & $18.4-22.8$ & $22.5-26.8$ & $23.6-25.9$ \\
\hline Upper caudal-lobe length (\% SL) & $15.2-20.8$ & $23.6-26.9$ & $18.7-23.9$ \\
\hline Caudal-peduncle length (\% SL) & $14.6-20.0$ & $12.1-15.8$ & $11.8-13.5$ \\
\hline Dorsal-fin length (\% SL) & $9.0-11.6$ & $13.7-18.0$ & $11.0-14.6$ \\
\hline Anal-fin length (\% SL) & $8.1-11.4$ & $13.0-17.7$ & $15.3-16.8$ \\
\hline
\end{tabular}

Fin rays flexible. Dorsal fin with 4 unbranched and 8 branched rays; distal margin slightly concave; origin slightly anterior to or superior to pelvic-fin insertion and closer to caudal-fin base than to snout tip. Pectoral fin with 1 unbranched and 10-11 

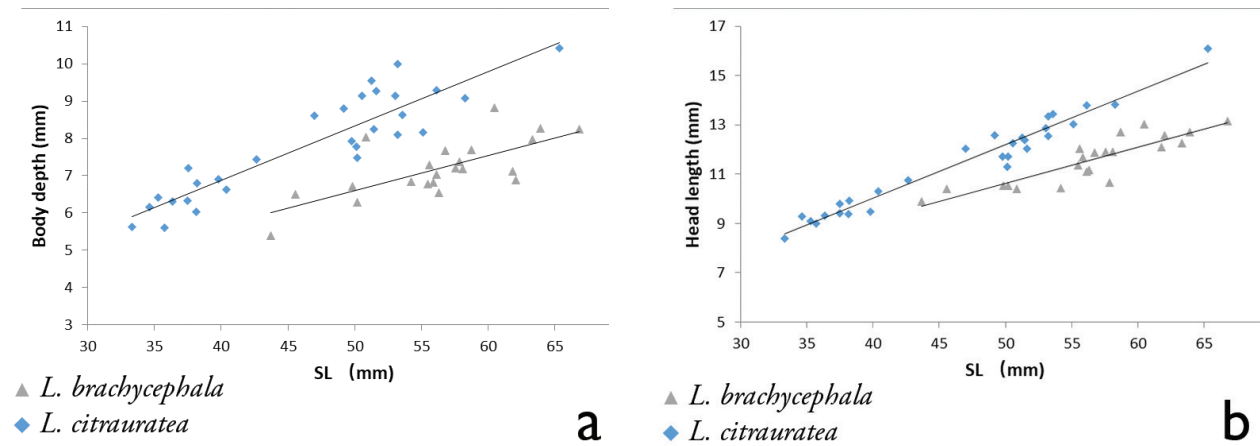

a $\diamond$. citrauratea

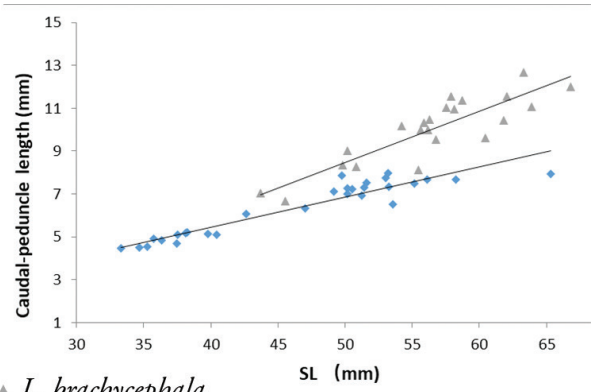

L. brachycephala

b

- L. citrauratea

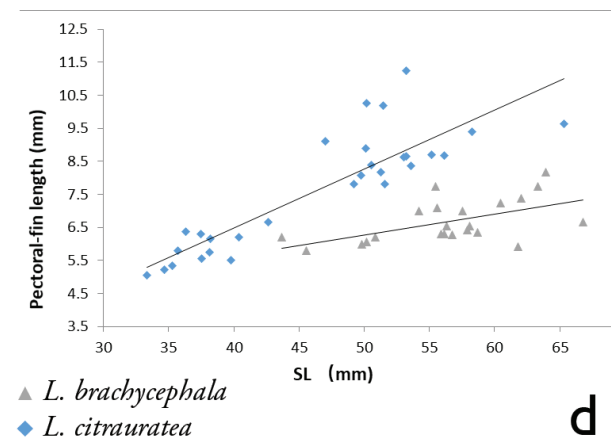

Figure 2. Relationship between body depth and SL (a), between head length and SL (b), between caudal-peduncle length and SL (c) and between pectoral-fin length and SL (d) for two closely-related species: L. brachycephala (gray triangle) and L. citrauratea (light blue diamond).

branched rays, tip of depressed fin extending about midway between pectoral-fin and pelvic-fin insertion. Pelvic fin with 1 unbranched and 7 branched rays, reaching about half of distance between pelvic-fin insertion and anal-fin origin and just reaching anus. Anus closer to anal-fin insertion than pelvic-fin insertion. Anal fin with 3 unbranched and 5 branched rays, tip of depressed fin not extending to caudal-fin base; distal margin slightly concave. Caudal fin strongly forked, median fin rays 1.7-2.3 times as long as lobes; upper and lower lobes broadly pointed and almost equal in length and shape.

Colouration. In freshly-collected specimens, ground colour of head and body yellowish-brown or orange; lateral head and flank faintly peppered with dark grey flecks. Dorsal side of head and body dark with some rounded light orange spots usually fused to form an orange stripe extending along mid-line of dorsum from nape to caudal-fin base. Anterior to orange spots or light stripe, an orangish stripe present between eye and nape. Faint dark grey stripe extending from snout tip to anterior margin of eye. Grey bar, similar in width to eye diameter, present on caudal-fin base. In some specimens, caudal fin hyaline, in others with dark grey stripes. Single row of faint dark grey stripes present in dorsal fin.

In specimens preserved in formalin, ground colour slightly faded, not presenting vivid yellowish-brown or orange, but becoming whitish-grey and peppered with dark flecks. Dorsum and head darkened. Orange spots along mid-line of dorsum white. 


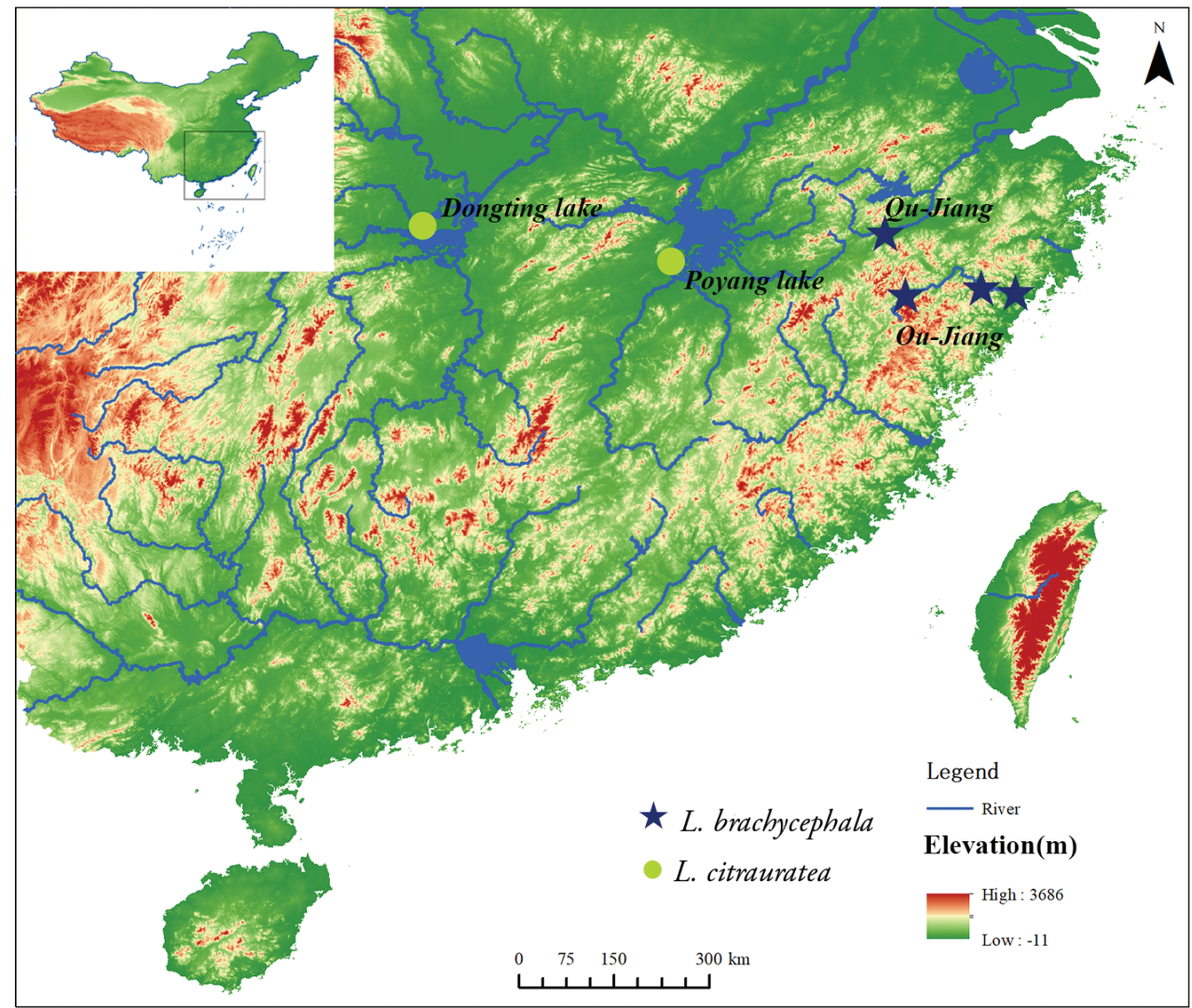

Figure 3. Collection localities of L. brachycephala (dark blue star) and L. citrauratea (light green dot).

Dorsal, pectoral, pelvic and anal fins greyish-yellow at base with white distal margins. Caudal fin dusky.

Geographical distribution and habitat. Leptobotia citrauratea is known from Dongting Lake in Hunan Province and the Gan-Jiang, discharging into Poyang Lake, in Jiangxi Province, southern China (Fig. 3). The specimens here described were collected in deep and slow-running water with mixed substrate. Syntopic fish species included Saurogobio dabryi Bleeker, 1871, Parabotia banarescui (Nalbant, 1965) and Hemibarbus maculatus Bleeker, 1871.

\section{Leptobotia brachycephala sp. nov.}

http://zoobank.org/4A74D0D5-5A3B-4458-8227-B67A591A4143

(Fig. 4a, b)

Holotype. IHB 201909037510, 63.9 mm SL; China: Zhejiang Province: Qingtian County: a stream discharging into the Ou-Jiang; $28^{\circ} 10^{\prime} 20^{\prime \prime} \mathrm{N}, 120^{\circ} 12^{\prime} 51^{\prime \prime E}$; collected by E Zhang and D.M. Guo, 8 October 2018. 

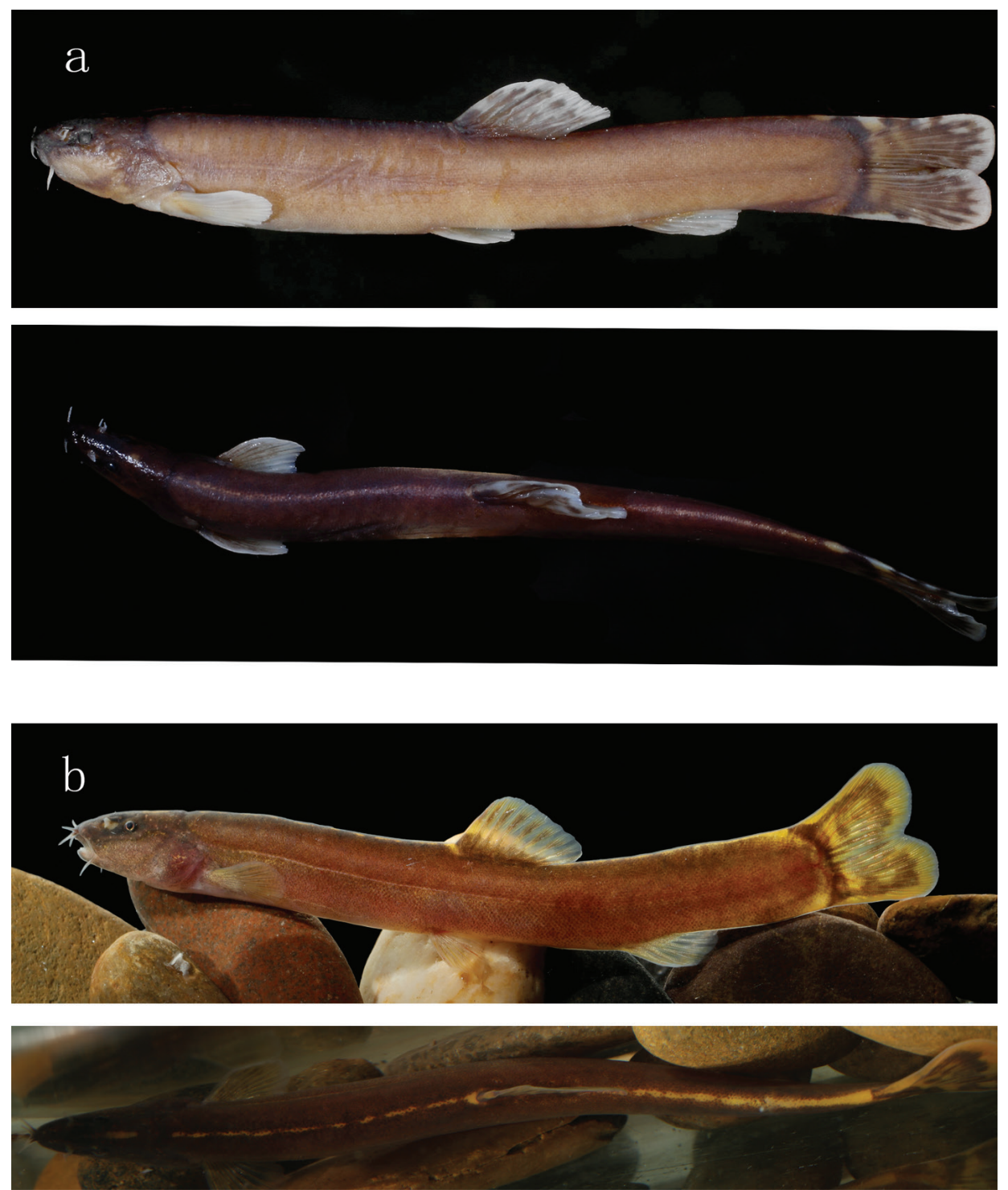

Figure 4. Lateral (upper) and dorsal (lower) view of body for L. brachycephala: a IHB 201909037510, holotype, $63.9 \mathrm{~mm}$ SL, China, Zhejiang Province, Lishui City, Qingtian County, Ou-Jiang, kept in formalin preservative after capture b IHB 2017056867, paratype, $62.5 \mathrm{~mm} \mathrm{SL}$, freshly collected from Qu-Jiang at Kecheng District, Quzhou City, Zhejiang Province.

Paratypes. IHB 2017056858, 2017056869-80, 13 specimens, 54.2-66.8 mm SL; China: Zhejiang Province: Quzhou City: a stream flowing into the Qu-Jiang; 28 57'6"N, 11851'15" E; collected by D.M. Guo, 15 December 2019.

Non-types examined. IHB 64VI410-15, 930138-39, 8 specimens, 43.7-60.5 mm SL; China: Zhejiang Province: Longquan City: a stream flowing into the Ou-Jiang; $28^{\circ} 4^{\prime} 12^{\prime \prime} \mathrm{N}, 119^{\circ} 6^{\prime} 54 " \mathrm{E}$; collected in 1964 and 1983. 
Diagnosis. Leptobotia brachycephala, together with L. citrauratea and L. micra, is distinguished from all other congeneric species by the presence (vs. absence) of a row of orange dots or an orange stripe extending along the dorsal mid-line of the body from the nape to the caudal-fin base (Fig. 4a, b: lower). It differs from L. citrauratea and L. micra in having an emarginate (vs. forked) caudal fin with two rounded (vs. broadly pointed) lobes (Figs 1a-c, 4a, b: upper), a shorter head (18.4-22.8\% SL vs. $22.5-26.8 \%$ SL in L. citrauratea and $23.6-25.9 \%$ SL in L. micra), a slender caudal peduncle (14.6-20.0\% SL vs. 12.1-15.8\% SL in L. citrauratea and $11.8-13.5 \%$ SL in L. micra), a shorter dorsal fin $(9.0-11.6 \%$ SL vs. $13.7-18 \%$ SL in L. citrauratea and 11.0-4.6\% SL in $L$. micra) and a shorter anal fin $(8.1-11.4 \%$ SL vs. $13.0-17.7 \%$ SL in L. citrauratea and $15.3-16.8 \%$ SL in L. micra) (Table 2, Fig. 2).

Description. Morphometric data given in Tables 1, 2. See Fig. 4 for lateral and dorsal view of body. Body slender, strongly compressed laterally, with greatest depth at dorsal-fin origin. Dorsal profile of head rising progressively from tip of snout to nape, from there to caudal-fin base nearly straight. Ventral profile of head slightly concave; ventral profile of body almost straight or slightly concave. Lateral line nearly complete, extending along mid-lateral body to terminate in median caudal-fin rays. Cheek and trunk covered with some minute scales.

Head short, compressed laterally, longer than maximum body depth. Snout slightly obtuse in lateral view, slightly shorter than postorbital head. Eye small, dorsolateral, in upper half of head; diameter less than interorbital width. Mouth inferior, with opening laterally extended to vertical through anterior margin of nostril. Button-like structures in gular region absent; no median incisions in lower lip. Two rostral barbels at tip of snout. Maxillary barbel in corner of mouth, not reaching to level of anterior margin of eye. Simple suborbital spine ventral to anterior margin of eye, not or just reaching posterior margin of eye.

Fin rays flexible. Dorsal fin with 4 unbranched and 8 branched rays; distal margin slightly concave; origin slightly posterior to pelvic-fin insertion and closer to caudal-fin base than to tip of snout. Pectoral fin with 1 unbranched and 10-11 branched rays, not extending to midway from pectoral-fin to pelvic-fin insertion. Pelvic fin with 1 unbranched and 7 branched rays, not extending to halfway to anal-fin origin or not reaching anus; vent closer to anal-fin origin than to pelvic-fin insertion. Anal fin with 3 unbranched and 5 branched rays, not reaching caudal-fin base; distal margin slightly concave; origin closer to pelvic-fin insertion than to caudal-fin base. Caudal fin emarginate or shallowly forked, length of median fin rays 1.3-1.5 times in length of upper lobe; caudal-fin lobes rounded; upper and lower ones almost equal in length and shape.

Colouration. In freshly-caught specimens, ground colour of head and body brownish-yellow; darker in upper half of head, but lighter in lower half of head and ventral side of body. A continuous or discontinuous orange stripe along mid-line of dorsum from nape to caudal-fin base, becoming more conspicuous towards caudal-fin base. Anterior to orange stripe, a short orange stripe present between eye and anterior margin of nape. A dark grey stripe on basal portion of dorsal fin and one stripe on dorsal fin. A dark grey band at caudal-fin base. Some irregular black stripes on caudal 


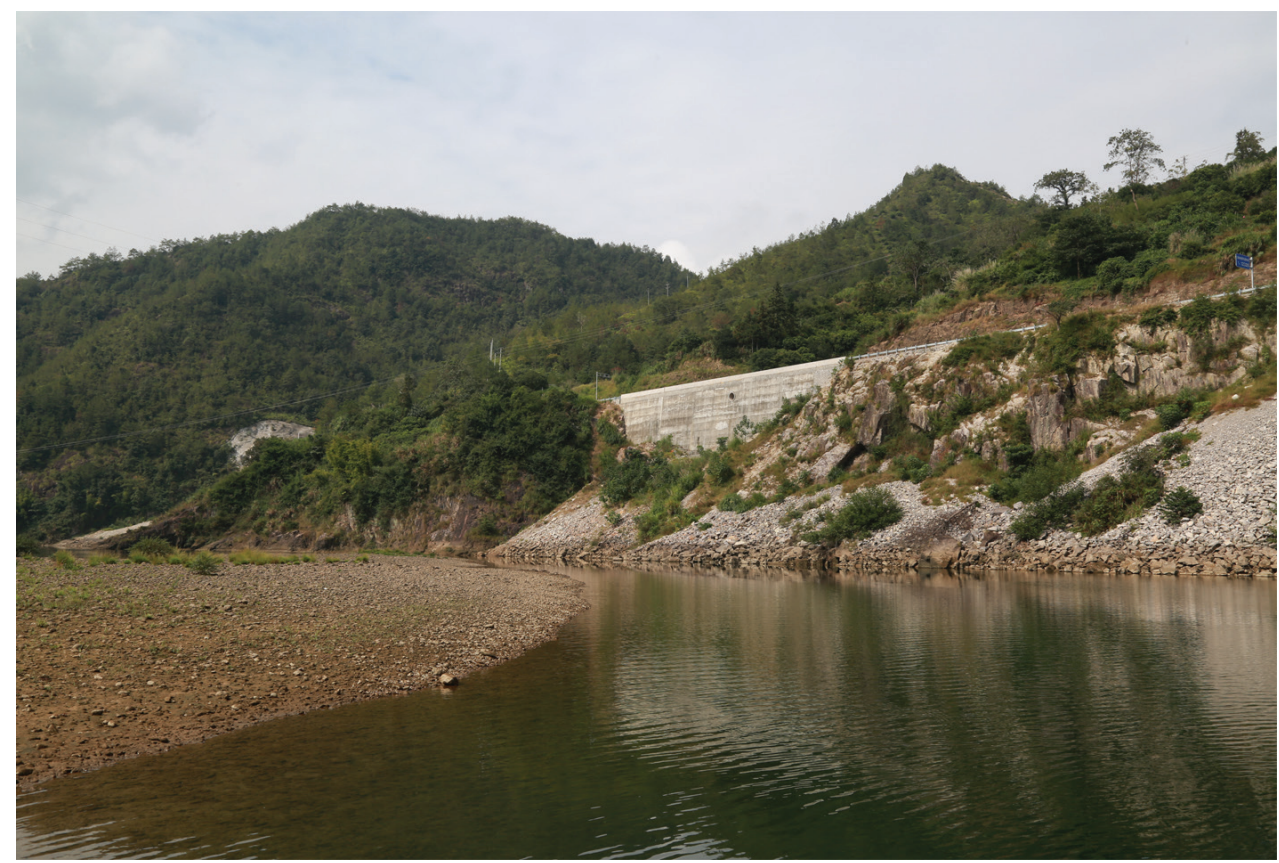

Figure 5. Type locality of $L$. brachycephala: fast-flowing clear water with mixed substrate including pebbles, gravels and boulders.

fin with hyaline distal edge. Distinct stripes absent from other fins. Specimens stored in formalin with ground colour of head and body pale brown. Discontinuous or continuous white line along dorsal mid-line of body also faded.

Geographical distribution and habitat. Leptobotia brachycephala is known only from the $\mathrm{Ou}$-Jiang and $\mathrm{Qu}-\mathrm{Jiang}$, two coastal rivers of southern Zhejiang Province, China (Fig. 3). Type specimens were caught in fast-flowing clear water with mixed substrate including pebbles, gravels and boulders (Fig. 5). Syntopic species included Sarcocheilichthys parvus Nichols, 1930, Acrossocheilus wenchowensis Wang, 1935, Cobitis sinensis Sauvage \& Dabry de Thiersant, 1874 and Rhinogobius giurinus (Rutter, 1897).

Explanation of name. The specific epithet is a Latin version of the Greek words $\beta \varrho \alpha \chi \dot{\nu} \varsigma$ (short) and $x \varepsilon \varphi \alpha \lambda \dot{\alpha}$ (head), with reference to the short head; to be treated as a noun in apposition.

Genetic comparisons. A total of 50 unique haplotypes were detected amongst the 103 cyt b sequences of species of Leptobotia (Table 3). The fragment contained 784 conserved sites, 276 variable sites, 233 parsimony informative sites and 43 singleton sites. The average frequency of four nucleotides of $L$. citrauratea was $\mathrm{A}=27.8 \%, \mathrm{~T}=$ $27.8 \%, C=30.3 \%$ and $\mathrm{G}=14.1 \%$. The intraspecific genetic distance, calculated for sampled species of Leptobotia with more than one haplotype, varied from $0.1 \%$ to $0.8 \%$. Leptobotia citrauratea is separated from other congeneric species by high genetic divergences of $2.9 \%$ to $10.5 \%$; its intraspecific genetic distance was $0.4 \%$. The genetic 
Table 3. Species included in this analysis with specimen voucher, sampling location and basin, haplotype and GenBank accession number; the haplotype with * means downloaded from GenBank.

\begin{tabular}{|c|c|c|c|c|c|c|}
\hline Species & Specimen voucher & Sampling location & Basin & Haplotype & GenBank no. & Source \\
\hline L. brachycephala & 201909034355 & Wenzhou, Zhejiang Prov. & Ou-Jiang & H1 & MT747394 & This study \\
\hline L. brachycephala & 201909034354 & Wenzhou, Zhejiang Prov. & Ou-Jiang & H1 & MT747394 & This study \\
\hline L. brachycephala & 201909034353 & Wenzhou, Zhejiang Prov. & Ou-Jiang & $\mathrm{H} 1$ & MT747394 & This study \\
\hline L. brachycephala & 201909034352 & Wenzhou, Zhejiang Prov. & Ou-Jiang & $\mathrm{H} 1$ & MT747394 & This study \\
\hline L. brachycephala & IHB2017056869 & Quzhou, Zhejiang Prov. & Qu-Jiang & $\mathrm{H} 1$ & MT747394 & This study \\
\hline L. brachycephala & IHB2017056870 & Quzhou, Zhejiang Prov. & Qu-Jiang & H1 & MT747394 & This study \\
\hline L. brachycephala & IHB2017056871 & Quzhou, Zhejiang Prov. & Qu-Jiang & $\mathrm{H} 1$ & MT747394 & This study \\
\hline L. brachycephala & IHB20181010544 & Qingtian, Zhejiang Prov. & Ou-Jiang & H1 & MT747394 & This study \\
\hline L. brachycephala & 201909034349 & Wenzhou, Zhejiang Prov. & Ou-Jiang & $\mathrm{H} 2$ & MT747395 & This study \\
\hline L. brachycephala & IHB20181010537 & Qingtian, Zhejiang Prov. & Ou-Jiang & $\mathrm{H} 3$ & MT747396 & This study \\
\hline L.tientainensis & IHB2017056861 & Jingdezhen, Jiangxi Prov. & Rao-He & $\mathrm{H} 1$ & MT747348 & This study \\
\hline L.tientainensis & IHB2017056836 & Jingdezhen, Jiangxi Prov. & Rao-He & $\mathrm{H} 1$ & MT747348 & This study \\
\hline L.tientainensis & IHB2017056835 & Jingdezhen, Jiangxi Prov. & Rao-He & H1 & MT747348 & This study \\
\hline L.tientainensis & IHB2017056834 & Jingdezhen, Jiangxi Prov. & Rao-He & $\mathrm{H} 1$ & MT747348 & This study \\
\hline L.tientainensis & IHB2017056833 & Jingdezhen, Jiangxi Prov. & Rao-He & $\mathrm{H} 1$ & MT747348 & This study \\
\hline L.tientainensis & 201909034356 & Linhai, Zhejiang Prov. & Ling-Jiang & $\mathrm{H} 1$ & MT747348 & This study \\
\hline L.tchangi & IHB2018099882 & Shaoxing, Zhejiang Prov. & Cao'e-Jiang & H1 & MT747349 & This study \\
\hline L.tchangi & IHB2018099861 & Shaoxing, Zhejiang Prov. & Cao'e-Jiang & H1 & MT747349 & This study \\
\hline L.tchangi & 201909034361 & Shaoxing, Zhejiang Prov. & Cao'e-Jiang & H1 & MT747349 & This study \\
\hline L.tchangi & IHB2018099848 & Quzhou, Zhejiang Prov. & Qu-Jiang & $\mathrm{H} 2$ & MT747350 & This study \\
\hline L.tchangi & IHB201904029046 & Hangzhou, Zhejiang Prov. & Qiantang-Jiang & $\mathrm{H} 2$ & MT747350 & This study \\
\hline L.tchangi & IHB201904029045 & Hangzhou, Zhejiang Prov. & Qiantang-Jiang & $\mathrm{H} 2$ & MT747350 & This study \\
\hline L.tchangi & 201904028852 & Hangzhou, Zhejiang Prov. & Qiantang-Jiang & $\mathrm{H} 2$ & MT747350 & This study \\
\hline L.tchangi & IHB2018099847 & Quzhou, Zhejiang Prov. & Qu-Jiang & H3 & MT747351 & This study \\
\hline L.tchangi & IHB2018099846 & Quzhou, Zhejiang Prov. & Qu-Jiang & $\mathrm{H} 4$ & MT747352 & This study \\
\hline L.tchangi & IHB2018099845 & Quzhou, Zhejiang Prov. & Qu-Jiang & $\mathrm{H} 4$ & MT747352 & This study \\
\hline L.tchangi & IHB2018099844 & Quzhou, Zhejiang Prov. & Qu-Jiang & H5 & MT747353 & This study \\
\hline L.tchangi & IHB201904029047 & Hangzhou, Zhejiang Prov. & Qiantang-Jiang & H6 & MT747354 & This study \\
\hline L.tchangi & IHB201904029044 & Hangzhou, Zhejiang Prov. & Qiantang-Jiang & H6 & MT747354 & This study \\
\hline L.taeniops & IHB2017056865 & Nanchang, Jiangxi Prov. & Gan-Jiang & $\mathrm{H} 1$ & MT747355 & This study \\
\hline L.taeniops & IHB2017056864 & Nanchang, Jiangxi Prov. & Gan-Jiang & $\mathrm{H} 2$ & MT747356 & This study \\
\hline L.taeniops & 201711015714 & Yiyang, Hunan Prov. & Zi-Shui & $\mathrm{H} 2$ & MT747356 & This study \\
\hline L.taeniops & 201711015711 & Yiyang, Hunan Prov. & Zi-Shui & $\mathrm{H} 2$ & MT747356 & This study \\
\hline L.taeniops & 201711015710 & Yiyang, Hunan Prov. & Zi-Shui & $\mathrm{H} 2$ & MT747356 & This study \\
\hline L.taeniops & 2017101867 & Yuanjiang, Hunan Prov. & Zi-Shui & $\mathrm{H} 2$ & MT747356 & This study \\
\hline L.taeniops & 2017101866 & Yuanjiang, Hunan Prov. & Zi-Shui & $\mathrm{H} 2$ & MT747356 & This study \\
\hline L.taeniops & 201711010290 & Yiyang, Hunan Prov. & Zi-Shui & $\mathrm{H} 2$ & MT747356 & This study \\
\hline L.taeniops & 201711010026 & Yiyang, Hunan Prov. & Zi-Shui & $\mathrm{H} 2$ & MT747356 & This study \\
\hline L.taeniops & IHB2017056863 & Nanchang, Jiangxi Prov. & Gan-Jiang & $\mathrm{H} 3$ & MT747357 & This study \\
\hline L.taeniops & 201711015671 & Yiyang, Hunan Prov. & Zi-Shui & $\mathrm{H} 3$ & MT747357 & This study \\
\hline L.taeniops & 201801016175 & Yiyang, Hunan Prov. & Zi-Shui & $\mathrm{H} 4$ & MT747358 & This study \\
\hline L.taeniops & 2017101865 & Yuanjiang, Hunan Prov. & Zi-Shui & H5 & MT747359 & This study \\
\hline L. rubrilabris & 201904028870 & Neijiang, Sichuan Prov. & Upper Chang-Jiang & H1 & MT747360 & This study \\
\hline L. rubrilabris & 201904028867 & Neijiang, Sichuan Prov. & Upper Chang-Jiang & $\mathrm{H} 2$ & MT747361 & This study \\
\hline L. rubrilabris & 201904028858 & Neijiang, Sichuan Prov. & Upper Chang-Jiang & $\mathrm{H} 2$ & MT747361 & This study \\
\hline L. rubrilabris & 201904028866 & Neijiang, Sichuan Prov. & Upper Chang-Jiang & $\mathrm{H} 3$ & MT747362 & This study \\
\hline L. rubrilabris & 201904028865 & Neijiang, Sichuan Prov. & Upper Chang-Jiang & $\mathrm{H} 4$ & MT747363 & This study \\
\hline L. rubrilabris & 201904028863 & Neijiang, Sichuan Prov. & Upper Chang-Jiang & $\mathrm{H} 5$ & MT747364 & This study \\
\hline L.punctata & 201909037450 & Baise, Guangxi Prov. & Zhu-Jiang & H1 & MT747365 & This study \\
\hline L.punctata & 018099887 & Liuzhou, Guangxi Prov. & Zhu-Jiang & H1 & MT747365 & This study \\
\hline L.punctata & 201909037448 & Baise, Guangxi Prov. & Zhu-Jiang & $\mathrm{H} 2$ & MT747366 & This study \\
\hline L.punctata & 201909037447 & Baise, Guangxi Prov. & Zhu-Jiang & $\mathrm{H} 2$ & MT747366 & This study \\
\hline L.punctata & 201909037446 & Baise, Guangxi Prov. & Zhu-Jiang & $\mathrm{H} 3$ & MT747367 & This study \\
\hline L.punctata & 201909037445 & Baise, Guangxi Prov. & Zhu-Jiang & $\mathrm{H} 4$ & MT747368 & This study \\
\hline L.punctata & 018099886 & Liuzhou, Guangxi Prov. & Zhu-Jiang & $\mathrm{H} 4$ & MT747368 & This study \\
\hline L.punctata & 018099885 & Liuzhou, Guangxi Prov. & Zhu-Jiang & $\mathrm{H} 5$ & MT747369 & This study \\
\hline L. pellegrini & IHB2018099886 & Liuzhou, Guangxi Prov. & Zhu-Jiang & H1 & MT747370 & This study \\
\hline
\end{tabular}




\begin{tabular}{|c|c|c|c|c|c|c|}
\hline Species & Specimen voucher & Sampling location & Basin & Haplotype & GenBank no. & Source \\
\hline L. pellegrini & IHB2018099885 & Liuzhou, Guangxi Prov. & Zhu-Jiang & $\mathrm{H} 2$ & MT747371 & This study \\
\hline L. pellegrini & IHB2018099884 & Liuzhou, Guangxi Prov. & Zhu-Jiang & $\mathrm{H} 2$ & MT747371 & This study \\
\hline L. pellegrini & IHB2018099840 & Liuzhou, Guangxi Prov. & Zhu-Jiang & $\mathrm{H} 2$ & MT747371 & This study \\
\hline L. pellegrini & IHB2018099839 & Liuzhou, Guangxi Prov. & Zhu-Jiang & $\mathrm{H} 2$ & MT747371 & This study \\
\hline L. pellegrini & 201909034360 & Liuzhou, Guangxi Prov. & Zhu-Jiang & $\mathrm{H} 2$ & MT747371 & This study \\
\hline L. pellegrini & 201909034359 & Liuzhou, Guangxi Prov. & Zhu-Jiang & $\mathrm{H} 2$ & MT747371 & This study \\
\hline L. pellegrini & 201909034358 & Liuzhou, Guangxi Prov. & Zhu-Jiang & $\mathrm{H} 2$ & MT747371 & This study \\
\hline L. microphthalma & 201904028856 & Neijiang, Sichuan Prov. & Upper Chang-Jiang & $\mathrm{H} 1$ & MT747372 & This study \\
\hline L. microphthalma & 201904028850 & Neijiang, Sichuan Prov. & Upper Chang-Jiang & $\mathrm{H} 1$ & MT747372 & This study \\
\hline L. microphthalma & 201904028855 & Neijiang, Sichuan Prov. & Upper Chang-Jiang & $\mathrm{H} 2$ & MT747373 & This study \\
\hline L. microphthalma & IHB2016105308 & Leshan, Sichuan Prov. & Min-Jiang & $\mathrm{H} 2$ & MT747373 & This study \\
\hline L. microphthalma & IHB2016105306 & Leshan, Sichuan Prov. & Min-Jiang & $\mathrm{H} 2$ & MT747373 & This study \\
\hline L. microphthalma & IHB2016105311 & Leshan, Sichuan Prov. & Min-Jiang & H3 & MT747374 & This study \\
\hline L. microphthalma & IHB2016105307 & Leshan, Sichuan Prov. & Min-Jiang & $\mathrm{H} 3$ & MT747374 & This study \\
\hline L. microphthalma & IHB2016105310 & Leshan, Sichuan Prov. & Min-Jiang & $\mathrm{H} 4$ & MT747375 & This study \\
\hline L. microphthalma & IHB2016105309 & Leshan, Sichuan Prov & Min-Jiang & $\mathrm{H} 5$ & MT747376 & This study \\
\hline L. hengyangensis & 2017042831 & Hengyang, Hunan Prov & Xiang-Jiang & $\mathrm{H} 1$ & MT747377 & This study \\
\hline L. hengyangensis & 2017042828 & Hengyang, Hunan Prov & Xiang-Jiang & $\mathrm{H} 2$ & MT747378 & This study \\
\hline L.guilinensis & 2015040820 & Guilin, Guangxi Prov & Zhu-Jiang & $\mathrm{H} 1$ & MT747379 & This study \\
\hline L.guilinensis & 2015040812 & Guilin, Guangxi Prov & Zhu-Jiang & $\mathrm{H} 1$ & MT747379 & This study \\
\hline L.guilinensis & 2015040811 & Guilin, Guangxi Prov & Zhu-Jiang & $\mathrm{H} 1$ & MT747379 & This study \\
\hline L.guilinensis & 2015040810 & Guilin, Guangxi Prov & Zhu-Jiang & $\mathrm{H} 1$ & MT747379 & This study \\
\hline L.guilinensis & 2015040805 & Guilin, Guangxi Prov & Zhu-Jiang & $\mathrm{H} 1$ & MT747379 & This study \\
\hline L.guilinensis & 2015040818 & Guilin, Guangxi Prov & Zhu-Jiang & $\mathrm{H} 2$ & MT747380 & This study \\
\hline L.guilinensis & 2015040815 & Guilin, Guangxi Prov & Zhu-Jiang & $\mathrm{H} 2$ & MT747380 & This study \\
\hline L.guilinensis & 2015040813 & Guilin, Guangxi Prov & Zhu-Jiang & H3 & MT747381 & This study \\
\hline L.guilinensis & 2015040808 & Guilin, Guangxi Prov & Zhu-Jiang & $\mathrm{H} 4$ & MT747382 & This study \\
\hline L. elongata & IHB2018059216 & Leshan, Sichuan Prov & Min-Jiang & $\mathrm{H} 1$ & MT747383 & This study \\
\hline L. elongata & IHB2018059215 & Leshan, Sichuan Prov & Min-Jiang & $\mathrm{H} 2$ & MT747384 & This study \\
\hline L. elongata & SCULE007 & Unknown & & $\mathrm{H} 2^{*}$ & NC018764 & GenBank \\
\hline L. elongata & Unknown & Luzhou, Sichuan Prov & Upper Chang-Jiang & $\mathrm{H} 2^{*}$ & AY625715 & GenBank \\
\hline L. elongata & IHB2018059214 & Leshan, Sichuan Prov & Min-Jiang & $\mathrm{H} 3$ & MT747385 & This study \\
\hline L. elongata & 201904028849 & Leshan, Sichuan Prov & Min-Jiang & $\mathrm{H} 4$ & MT747386 & This study \\
\hline L. elongata & IAPG A214 & Unknown & & $\mathrm{H} 5^{*}$ & AY887779 & GenBank \\
\hline L. elongata & Unknown & Unknown & & $\mathrm{H} 6^{*}$ & KY307845 & GenBank \\
\hline L. citrauratea & IHB2017056860 & Nanchang, Jiangxi Prov & Gan-Jiang & $\mathrm{H} 1$ & MT747387 & This study \\
\hline L. citrauratea & IHB2017056859 & Nanchang, Jiangxi Prov & Gan-Jiang & $\mathrm{H} 2$ & MT747388 & This study \\
\hline L. citraurated & IHB2017056858 & Nanchang, Jiangxi Prov & Gan-Jiang & $\mathrm{H} 3$ & MT747389 & This study \\
\hline L. citrauratea & 201711016295 & Nanxian, Hunan Prov & Donngting Lake & $\mathrm{H} 3$ & MT747389 & This study \\
\hline L. citrauratea & 201711015674 & Nanxian, Hunan Prov & Donngting Lake & H3 & MT747389 & This study \\
\hline L. citrauratea & IHB2017056857 & Nanchang, Jiangxi Prov & Gan-Jiang & $\mathrm{H} 4$ & MT747390 & This study \\
\hline L. citrauratea & 201711016297 & Nanxian, Hunan Prov & Donngting Lake & $\mathrm{H} 5$ & MT747391 & This study \\
\hline L. citrauratea & 201711016296 & Nanxian, Hunan Prov & Donngting Lake & H6 & MT747392 & This study \\
\hline L. citrauratea & 201711015675 & Nanxian, Hunan Prov & Donngting Lake & H6 & MT747392 & This study \\
\hline L. citrauratea & 201711015716 & Nanxian, Hunan Prov & Donngting Lake & $\mathrm{H} 7$ & MT747393 & This study \\
\hline L. posterodorsalis & Unknown & Xiaoxi, Hunan Prov & Yuan-Jiang & $\mathrm{H} 1^{*}$ & MH922928 & GenBank \\
\hline P. fasciata & Unknown & Unknown & & $\mathrm{H} 1^{*}$ & AY625710 & GenBank \\
\hline P. lijiangensis & Unknown & Chenxi, Hunan Prov & Yuan-Jiang & $\mathrm{H} 1^{*}$ & AY625713 & GenBank \\
\hline
\end{tabular}

distance of $L$. brachycephala versus congeneric species ranged from $2.9 \%$ to $10.6 \%$; its intraspecific genetic distance was $0.1 \%$ (Table 4).

In the Bayesian $50 \%$ majority consensus tree, samples of L. brachycephala formed a well-supported (100\% pp) lineage and so did those of both L. citrauratea and L. elongata. L. citrauratea was distantly allied to L. elongata, but robustly supported by $100 \%$ pp to be sister to L. brachycephala (Fig. 6). 
Table 4. Genetic distances of the cyt b gene computed by MEGA 7 amongst 13 analysed species of Leptobotia.

\begin{tabular}{|c|c|c|c|c|c|c|c|c|c|c|c|c|c|}
\hline Species & Intraspecific & 1 & 2 & 3 & 4 & 5 & 6 & 7 & 8 & 9 & 10 & 11 & 12 \\
\hline 1 L. tientainensis & $\mathrm{n} / \mathrm{c}$ & & & & & & & & & & & & \\
\hline 2 L. tchangi & 0.003 & 0.078 & & & & & & & & & & & \\
\hline 3 L. taeniops & 0.003 & 0.081 & 0.058 & & & & & & & & & & \\
\hline 4 L. rubrilabris & 0.002 & 0.077 & 0.057 & 0.055 & & & & & & & & & \\
\hline 5 L. punctata & 0.004 & 0.106 & 0.104 & 0.111 & 0.096 & & & & & & & & \\
\hline 6 L.pellegrini & 0.002 & 0.077 & 0.064 & 0.073 & 0.061 & 0.107 & & & & & & & \\
\hline 7 L. microphthalma & 0.004 & 0.067 & 0.069 & 0.067 & 0.061 & 0.092 & 0.077 & & & & & & \\
\hline 8 L. hengyangensis & 0.008 & 0.069 & 0.041 & 0.057 & 0.047 & 0.098 & 0.059 & 0.059 & & & & & \\
\hline 9 L. guilinensis & 0.002 & 0.018 & 0.086 & 0.086 & 0.080 & 0.110 & 0.080 & 0.069 & 0.079 & & & & \\
\hline 10 L. elongata & 0.002 & 0.073 & 0.071 & 0.073 & 0.066 & 0.096 & 0.067 & 0.053 & 0.067 & 0.073 & & & \\
\hline 11 L. citrauratea & 0.004 & 0.079 & 0.075 & 0.069 & 0.062 & 0.105 & 0.076 & 0.061 & 0.069 & 0.080 & 0.071 & & \\
\hline $12 \mathrm{~L}$. posterodorsalis & $\mathrm{n} / \mathrm{c}$ & 0.066 & 0.069 & 0.074 & 0.068 & 0.104 & 0.069 & 0.070 & 0.066 & 0.069 & 0.068 & 0.065 & \\
\hline 13 L. brachycephala & 0.001 & 0.076 & 0.072 & 0.071 & 0.064 & 0.106 & 0.065 & 0.064 & 0.066 & 0.078 & 0.067 & 0.029 & 0.060 \\
\hline
\end{tabular}

Table 5. Loadings of morphological traits on the first three principal components. Variables in bold indicate higher loading values.

\begin{tabular}{lccc}
\hline & Variable & PC1 & PC3 \\
\hline Standard length & 0.224 & -0.150 & -0.079 \\
Body depth & 0.164 & 0.155 & 0.060 \\
Body width at dorsal origin & 0.163 & 0.123 & $\mathbf{0 . 2 8 7}$ \\
Head length & 0.169 & 0.050 & -0.002 \\
Head depth at nape & 0.165 & 0.173 & 0.112 \\
Head depth at eye & 0.148 & 0.150 & -0.100 \\
Caudal-peduncle length & 0.288 & -0.026 \\
Caudal-peduncle depth & 0.206 & $\mathbf{- 0 . 4 4 5}$ & $\mathbf{0 . 8 6 2}$ \\
Caudal-peduncle width & 0.169 & -0.138 & -0.025 \\
Dorsal-fin length & 0.197 & -0.118 \\
Pectoral-fin length & 0.187 & -0.237 & -0.124 \\
Pelvic-fin length & 0.176 & $\mathbf{0 . 3 7 5}$ & 0.014 \\
Anal-fin length & 0.199 & $\mathbf{0 . 2 4 1}$ & -0.031 \\
Upper caudal-lobe length & 0.162 & 0.144 & -0.082 \\
Predorsal length & 0.218 & $\mathbf{0 . 3 8 1}$ & -0.025 \\
Prepectoral length & 0.181 & $\mathbf{0 . 2 5 9}$ & -0.030 \\
Prepelvic length & 0.228 & -0.122 & -0.052 \\
Preanal length & 0.220 & 0.029 & -0.216 \\
Vent to anal-fin origin & 0.325 & -0.039 & -0.059 \\
Pelvic-fin insertion to anal-fin origin & 0.256 & -0.075 & 0.072 \\
Snout length & 0.186 & $-\mathbf{0 . 2 4 2}$ & -0.087 \\
Postorbital head length & 0.170 & -0.130 & -0.023 \\
Eye diameter & 0.180 & 0.076 & 0.099 \\
Interorbital width & 0.156 & -0.035 & -0.119 \\
Median caudal-ray length & 0.147 & 0.035 & 7.4 \\
Cumulative variance (\%) & 64.6 & 0.209 & -0.168 \\
\hline
\end{tabular}

Comparative morphometrics. In the Principal Component Analysis of specimens of L. citrauratea from Dongting Lake and the Gan-Jiang and L. brachycephala from the $\mathrm{Ou}$-Jiang and $\mathrm{Qu}$-Jiang, the first three components explained $91.60 \%$ of the total variance, of which $64.58 \%, 19.61 \%$ and $7.41 \%$ were explained, respectively by PC 1 , PC 2 and PC 3 (Table 5). In the scatterplot of PC 2 and PC 3 loadings (Fig. 7), specimens of L. citrauratea and L. brachycephala constituted two distinct clusters separated on the 


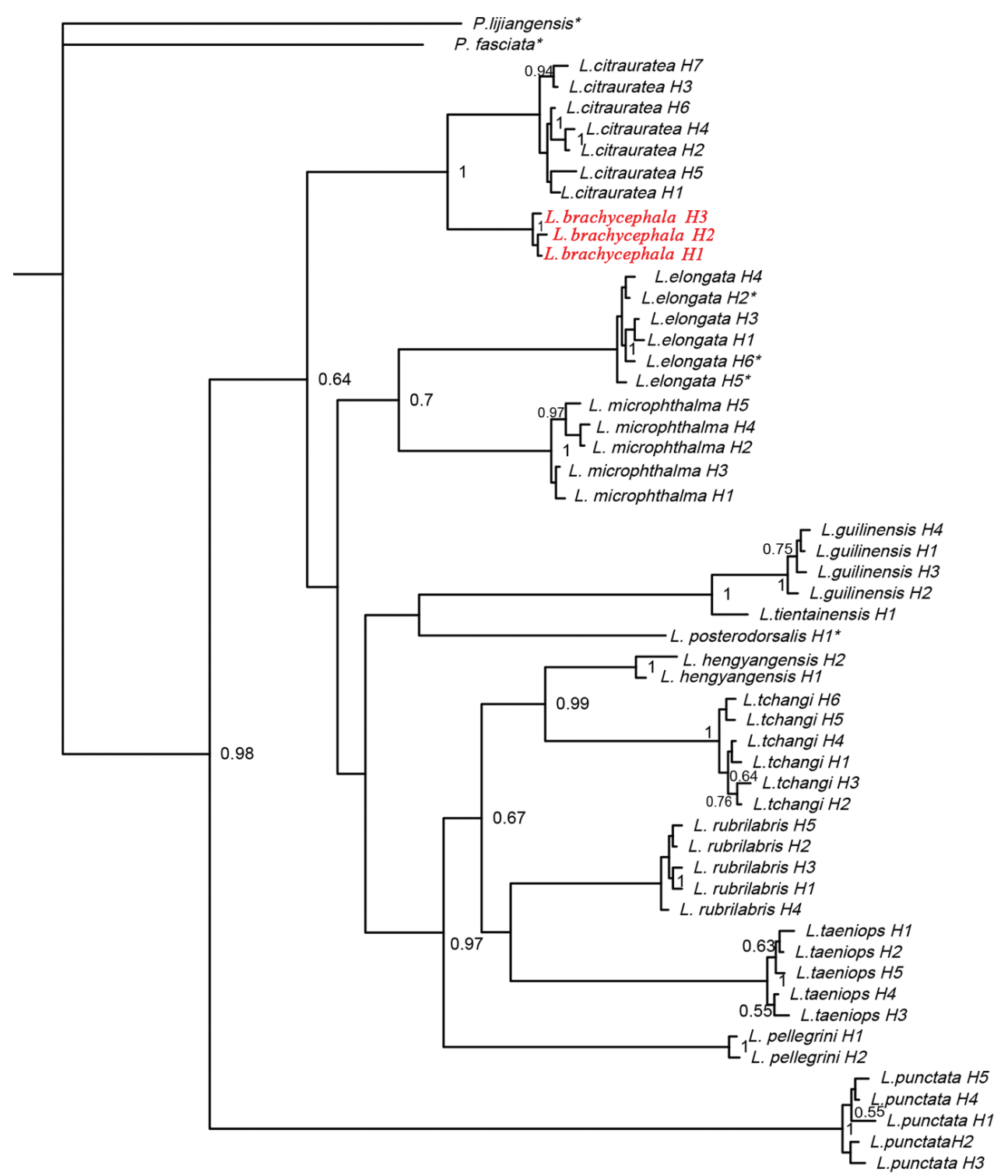

0.02

Figure 6. Bayesian Inference tree inferred from the cyt b gene for 13 analysed species of Leptobotia. Nodal numbers are posterior probability values greater than $50 \%$

PC 2 axis. Six characters with main loading on this axis were caudal-peduncle length, anal-fin length, dorsal-fin length, upper caudal-lobe length, pectoral-fin length and vent to anal-fin distance. Except for the last character, all of them exhibited differences in the morphometric comparisons. Table 2 and Fig. 2 show the main morphological characters. 


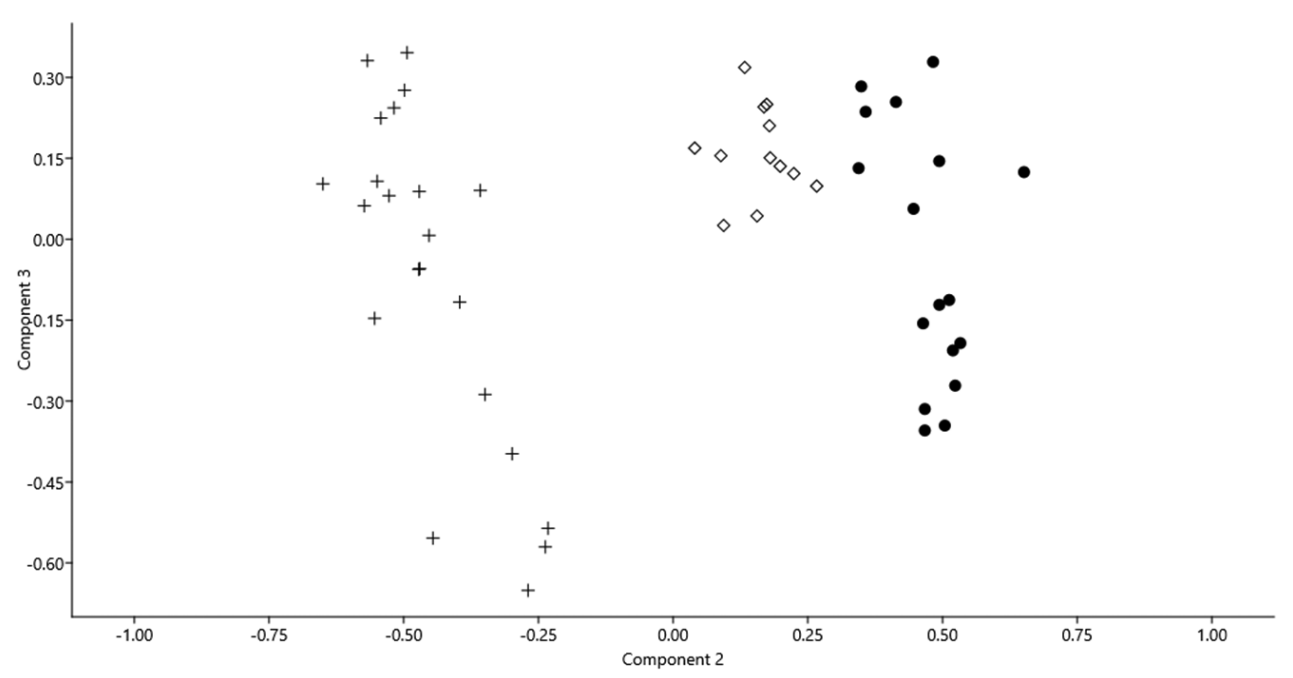

Figure 7. Scatter plot of the principal components II and principal components III, extracted from morphometric data of L. brachycephala: Ou-Jiang (plus symbol). L. citrauratea: Dongting Lake (black circle) and Gan-Jiang (white diamond).

\section{Discussion}

Nichols et al. (1925) described the colour of L. citrauratea as "purplish brown; yellowish below". This colouration is shared with freshly-caught specimens of this species from the Dongting Lake (type locality) and Poyang Lake systems (Fig. 1). Our examination of these topotypical specimens and a photograph of the holotype (AMNH 8402) (Fig. 1c) confirmed Bohlen and Šlechtovás (2016) observation that L. citrauratea has some round orange dots or an orange stripe along the dorsal mid-line of the body. There were no significant differences in morphometric measurements and meristic counts detected between specimens from the Dongting and Poyang Lake systems (Table 1).

Chen (1980) synonymised L. citrauratea with L. elongata, a species found in the mid-upper Chang-Jiang Basin, but without examination of their type specimens or even reference to topotypical specimens. This classification had been widely accepted by subsequent researchers until 2002 when Nalbant recognised L. citrauratea as valid. Morphological data, provided in this study, indicated that there were distinct variations between these two species. Topotypical specimens examined of $L$. citrauratea possessed a small-sized body of up to $70.0 \mathrm{~mm} \mathrm{SL}$, while the body size of L. elongata attained a length of 97.8 to $272.0 \mathrm{~mm}$ SL for available specimens caught from the upper ChangJiang Basin. The specimen of the species, caught by Fang (1936), reached up to 500 $\mathrm{mm}$ in total length. Leptobotia citrauratea has a series of small orange spots or an orange stripe along the dorsal mid-line of the body from the nape to the caudal-fin base, a yellowish-brown or orange ground colour of head and body and no black band crossing the dorsum (Fig. 1). This is contrast to L. elongata which, in light of its original account and our observation on specimens collected from the upper Chang-Jiang Basin, has a 

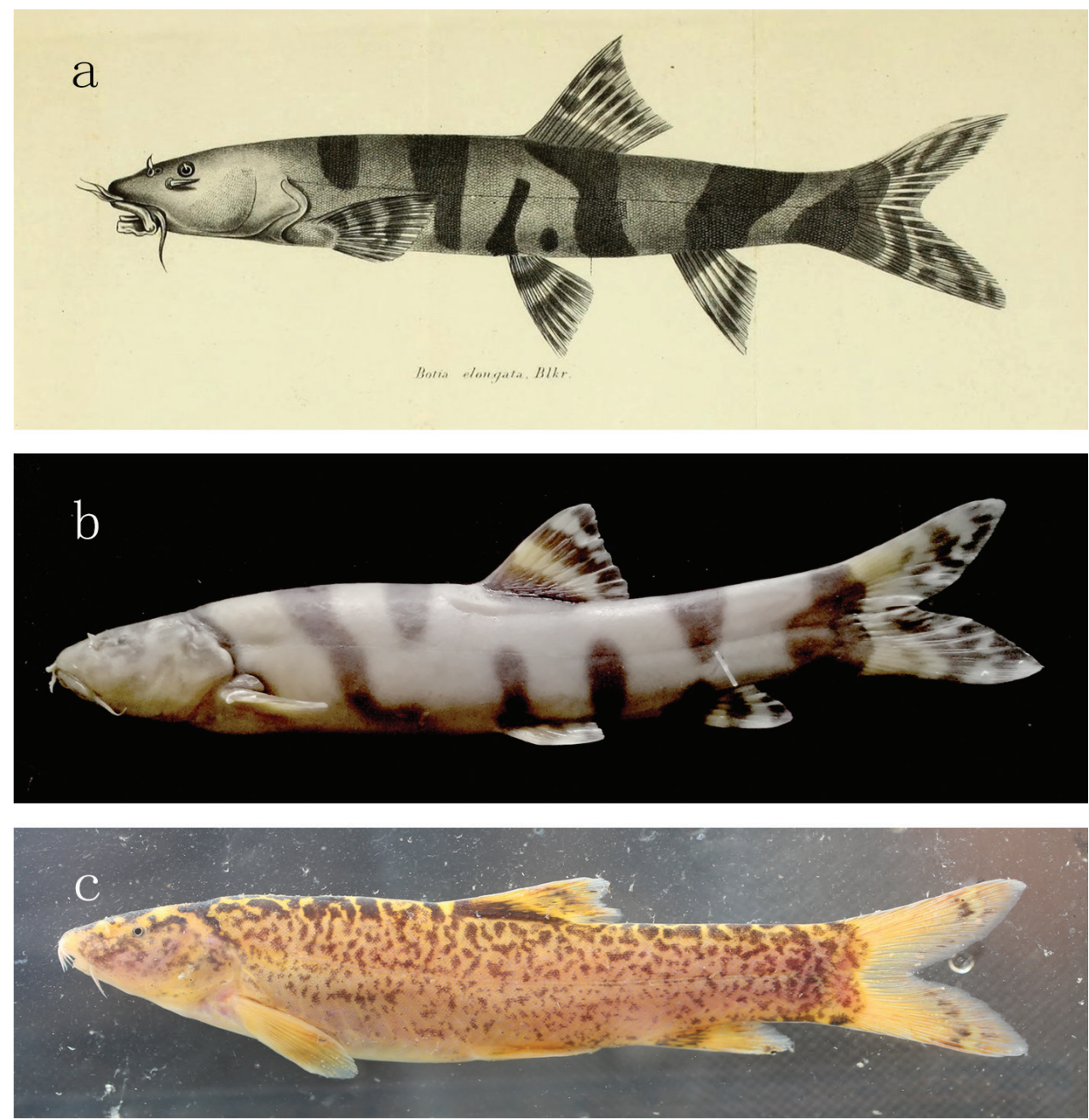

Figure 8. a a copy of Bleeker' (1870) illustration of L. elongata b lateral view of body for L. elongata in IHB 2018059214, 175.83 mm SL, China, Sichuan Province, Leshan City, upper Chang-Jiang Basin, kept in formalin preservative after capture c lateral view of body for L. taeniops in IHB 2017110267, $100.2 \mathrm{~mm}$ SL, freshly caught from Dongting Lake at Nanxian County, Yiyang City, Hunan Province, South China.

body colouration of many wide brown and transverse bands (Fig. 8a, b). Additionally, L. citrauratea differs from L. elongata in having larger eyes (diameter 9.2-12.1\% HL vs. $4.2-8.4 \%$ HL; see Table 1) and pelvic fin not or just reaching (vs. exceeding) the anus. Our molecular analysis also showed that $L$. citrauratea had a $7.1 \%$ interspecific genetic distance with $L$. elongata (Table 4 ) and that these two species constituted two independent lineages distantly related in the phylogenetic tree, based on the cyt b gene (Fig. 6). It is thus concluded here that $L$. citrauratea is a species distinct from L. elongata and confined only to the mid-lower Chang-Jiang Basin (the Dongting and Poyang Lake Basins); L. elongata is actually an endemic species of the upper Chang-Jiang Basin. 


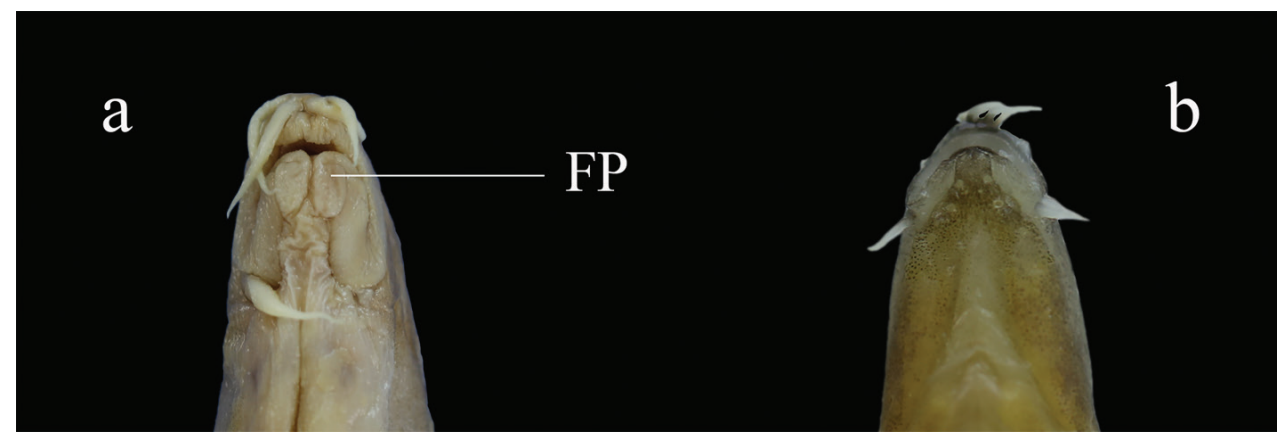

Figure 9. Ventral view of the mouth of two species a L. rubrilabris, IHB 581-032, $150.2 \mathrm{~mm}$ SL, China, Chongqing City, Banan District, upper Chang-Jiang b L. brachycephala, IHB 2017056872, Paratype, 66.8 mm SL, China, Zhejiang Province, Quzhou City, Kecheng District, Qu-Jiang. FP = fleshy protrusion.

Nichols et al. (1925) recognised three species of Botia from the Dongting Lake system: one previously-described species as Botia rubrilabris Dabry de Thiersant, 1872 and two new species, $B$. purpurea and $B$. citrauratea. These three species were later referred to Leptobotia where B. purpurea were synonymised with L. taeniops (Sauvage, 1878) (Chen 1980; Kottelat 2004, 2012). The latest report on the distribution of L. rubirilabris (Dabry de Thiersant, 1872) in this Lake was Anonymous (1980) who caught a single specimen of $80.0 \mathrm{~mm}$ SL. This specimen, in light of their description, has a buttonlike fleshy protrusion in the gular area, a character diagnostic for $L$. rubirilabris within this genus (Chen 1980); thus, it is conspecific with this species. Recent field surveys, conducted by us from 2014 to 2018 in Dongting Lake, yielded no specimens of this species. Likely, it was extirpated in this Basin. Leptobotia citrauratea mainly differs from L. rubrilabris, caught from the upper Chang-Jiang Basin (its type locality), in having a shorter (vs. longer) suborbital spine just reaching (vs. far beyond) the posterior margin of the eye and no button-like fleshy protrusion in the gular area (vs. present) (Fig. 9).

The specific status of $L$. brachycephala was confirmed by its morphological and genetic distinction with closely-related congeneric species (Tables 2-4). The PCA results showed that specimens of this species from southern Zhejiang Province formed a cluster, distinct from the one formed by specimens of $L$. citrauratea from the Dongting and Poyang Lake systems (Fig. 7). Although L. brachycephala was robustly supported by $100 \%$ pp to be sister to $L$. citrauratea, their interspecific genetic distance was $2.9 \%$.

The seventeen species currently included in Leptobotia can be subdivided into six groups, based on their body colourations. The first one is only composed of one species L. taeniops that has a unique body colouration of some irregular purplish-brown stripes in the shape of a worm on the flank, hence resulting in a marbled or vermiculated pattern (Fig. 8c). The second group, represented by L. punctata Li, Li \& Chen, 2008, has a lot of irregularly-organised white spots on the flank, giving a reticulated pattern. The third group, including L. pellegrini Fang, 1936, L. elongata, L. hengyangensis Huang \& Zhang, 1986, L. tchangi Fang, 1936 and L. rubrilabris, is characterised by having a body colouration of some broad brown-black blotches on the body or saddles on the 
dorsum. The fourth group is formed by the following four species: L. posterodorsalis, L. bellacauda Bohlen \& Šlechtová, 2016, L. tientainensis (Wu, 1930) and L. microphthalma $\mathrm{Fu} \& \mathrm{Ye}, 1983$, all of them having a plain brown body and no other colour formation. The fifth group has some rounded light orange spots extending along the mid-line of the dorsum from nape to caudal-fin base and three species are included in this group: L. micra, L. citrauratea and L. brachycephala. The last group has narrow bands on the body or mid-line of the back and three species can be referred to this group: L. guilinensis Chen, 1980, L. orientalis and L. flavolineata.

\section{Comparative material}

Leptobotia elongata: IHB 3609, 58199, 64V2269-70, 4 specimens, 189.6-224.7 mm SL, upper Chang-Jiang Basin at Yichang City, Hubei Province; IHB 201805921416, 3 specimens, 170.0-176.5 mm SL, upper Chang-Jiang Basin at Leshan City, Sichuan Province; IHB 790197, 790198-99, 3 specimens, 87.8-167.4 mm SL, upper Chang-Jiang Basin at Luzhou City, Sichuan Province; IHB 790349, 1 specimens, $161.0 \mathrm{~mm}$ SL, upper Chang-Jiang Basin at Yibin City, Sichuan Province; IHB 201909035604, 1 specimens, 272.0 mm SL, upper Chang-Jiang Basin at Liangshan Yi Autonomous Prefecture, Sichuan Province; IHB 585410, 501244, 73V1466, 420457, 590452-54, 580451, 8 specimens, 116.8-236.7 mm SL, upper ChangJiang Basin at Chongqing City; IHB 201909035958, 201909035934, 2 specimens, 100.7-110.7 mm SL, upper Chang-Jiang Basin at Zhaotong City, Yunnan Province. Leptobotia taeniops: IHB 2017100254-59, 2017110267, 7 specimens, 43.6-112.9 mm

SL, middle Chang-Jiang Basin at Yiyang City, Hunan Province; 201807020856, 201807028170, 2 specimens, 61.2-82.4 mm SL, middle Chang-Jiang Basin at Yueyang City, Hunan Province;

Leptobotia rubrilabris: IHB 581-032, 2 specimens, $150.2 \mathrm{~mm}$ SL, Dongting Lake at Nanxian County, Yiyang City, Hunan Province, South China;

Leptobotia tientainensis: IHB 74VI3347-50, 4 specimens, 70.5-91.2 mm SL, LingJiang at Taizhou City, Zhejiang Province;

Leptobotia guilinensis: IHB 2015040803, 1 specimen, $70.3 \mathrm{~mm}$ SL, Zhu-Jiang at Guilin City, Guangxi Province;

Leptobotia tchangi: IHB 201904029044, 1 specimen, 80.4 mm SL, Qiantang-Jiang at Hangzhou City, Zhejiang Province;

Leptobotia pellegrini: IHB 2018099839, 1 specimen, 103.2 mm SL, Zhu-Jiang at Liuzhou City, Guangxi Province;

Leptobotia hengyangensis: IHB 2017042831, 2017042828, 2 specimens, 99.7$102.8 \mathrm{~mm}$ SL, Xiang-Jiang at Hengyang City, Hunan Province;

Leptobotia microphthalma: IHB 2016105306, 1 specimen, 78.3 mm SL, upper ChangJiang Basin at Leshan City, Sichuan Province.

Data for L. bellacauda and L. micra were taken from Bohlen and Šlechtová (2016), (2017). 


\section{Acknowledgements}

Our sincere thanks go to Chang-Ting An, Xiao Chen, Wei-Han Shao, Zi-Tong Wang and Hao-Jun Chen for their kind assistance with collecting samples. In addition, we express our deepest gratitude to Liang Cao and Shu-Qing Deng for their help with laboratory analyses. This study was funded by two special funds of Biodiversity Survey, Monitoring and Assessment (2017HB2096001006 and 2019HB2096001006).

\section{References}

Anonymous (1980) The Fishes of Hunan. Hunan Science and Technology Press, Changsha, $163 \mathrm{pp}$.

Bohlen J, Šlechtová V (2016) Leptobotia bellacauda, a new species of loach from the lower Yangtze Basin in China (Teleostei: Cypriniformes: Botiidae). Zootaxa 4205: 65-72. https://doi. org/10.11646/zootaxa.4205.1.5

Bohlen J, Šlechtová V (2017) Leptobotia micra, a new species of loach (Teleostei: Botiidae) from Guilin, southern China. Zootaxa 4250:90-100. https://doi.org/10.11646/zootaxa.4250.1.7

Chen JX (1980) A study on the classification of the Botoid fishes of China. Zoological Research 1: 23-28.

Fang PW (1936) Study on botoid fishes of China. Sinensia 7: 1-49.

Hammer O, Harper D, Ryan P (2009) PAST-Palaeontological statistics, ver. 1.89. Palaeontologia Electronica 4: 1-92.

Kalyaanamoorthy S, Minh BQ, Wong TKF, von Haeseler A, Jermiin LS (2017) ModelFinder: fast model selection for accurate phylogenetic estimates. Nature Methods 14: 587-589. https://doi.org/10.1038/nmeth.4285

Katoh K, Misawa K, Kuma K, Miyata T (2002) MAFFT: a novel method for rapid multiple sequence alignment based on fast Fourier transform. Nucleic Acids Research 30(14): 3059-3066. https://doi.org/10.1093/nar/gkf436

Katoh K, Standley DM (2013) MAFFT multiple sequence alignment software version 7: improvements in performance and usability. Molecular Biology and Evolution 30: 772-780. https://doi.org/10.1093/molbev/mst010

Kottelat M (2001) Fishes of Laos. Wildlife Heritage Trust Publications, Colombo, 198 pp.

Kottelat M (2004) Botia kubotai, a new species of loach (Teleostei : Cobitidae) from the Ataran River basin (Myanmar), with comments on botiine nomenclature and diagnosis of a new genus. Zootaxa 401: 1-18. https://doi.org/10.11646/zootaxa.401.1.1

Kottelat M (2012) Conspectus Cobitinum: an inventory of the loaches of the world (Teleostei: Cypriniformes: Cobitoidei). Raffles Bulletin of Zoology Suppl 26: 1-199.

Kumar S, Stecher G, Tamura K (2016) MEGA7: Molecular Evolutionary Genetics Analysis version 7.0 for bigger datasets. Molecular Biology and Evolution 33(7): 1870-1874. https://doi.org/10.1093/molbev/msw054

Librado P, Rozas J (2009) DnaSP v5: a software for comprehensive analysis of DNA polymorphism data. Bioinformatics 25: 1451-1452. https://doi.org/10.1093/bioinformatics/btp187 
Nalbant TT (2002) Sixty million years of evolution. Part one: Family Botiidae (Pisces: Ostariophysi: Cobitoidea). Travaux du Muséum National d'Histoire Naturelle "Grigore Antipa” 44: 309-333.

Nichols JT, Pope CH, Caldwell HR, Granger W (1925) Some Chinese fresh-water fishes. I. Loaches of the genus Botia in the Yangtze Basin. II. A new minnow-like carp from Szechwan. III. The Chinese sucker, Myxocyprinus. American Museum Novitates 177: 1-9.

Ronquist F, Teslenko M, van der Mark P, Ayres DL, Darling A, Hohna S, Larget B, Liu L, Suchard MA, Huelsenbeck JP (2012) MrBayes 3.2: efficient Bayesian phylogenetic inference and model choice across a large model space. Systematic Biology 61: 539-542. https://doi.org/10.1093/sysbio/sys029

Tang QY, Yu D, Liu HZ (2008) Leptobotia zebra should be revised as Sinibotia zebra (Cypriniformes: Botiidae). Zoological Research 29(1): 1-9. https://doi.org/10.3724/ SP.J.1141.2008.00001

Wang HY (1981) On a new cobitid fish of the genus Leptobotia from Beijing. Memoirs of the Beijing Natural History Museum 12: 1-3.

Xu TQ, Fang SM, Wang HY (1981) A new species of fishes of the genus Leptobotia (family Cobitidae) from China. Zoological Research 2(4): 87-89.

Xiao WH, Zhang YP, Liu HZ (2001) Molecular systematics of Xenocyprinae (Teleostei: Cyprinidae): Taxonomy, biogeography, and coevolution of a special group restricted in east Asia. Molecular Phylogenetics and Evolution 18: 163-173. https://doi.org/10.1006/mpev.2000.0879

Xin Q, Zhang E, Cao WX (2009) Onychostoma virgulatum, a new species of cyprinid fish (Pisces: Teleostei) from southern Anhui Province, South China. Ichthyological Exploration of Freshwaters 20(3): 255-266.

Zhang D, Gao FL, Jakovlic I, Zou H, Zhang J, Li WX, Wang GT (2020) PhyloSuite: an integrated and scalable desktop platform for streamlined molecular sequence data management and evolutionary phylogenetics studies. Molecular Ecology Resources 20: 348-355. https://doi.org/10.1111/1755-0998.13096 